\title{
Should we take the gig economy seriously?
}

\author{
Joshua Healy*, Daniel Nicholson*, and Andreas Pekarek ${ }^{\#}$ \\ *Centre for Workplace Leadership, University of Melbourne, Australia \\ \#Department of Management and Marketing, University of Melbourne, Australia
}




\section{$\underline{\text { Abstract }}$}

The 'gig economy' has emerged rapidly as a form of service delivery that challenges existing business models, labour-management practices, and regulations. The ways in which platform companies transact with workers, in particular, has created a burgeoning public interest, but has yet to give rise to a corresponding academic literature. In this paper, we ask whether the gig economy deserves to be a subject of employment relations scholarship, given its current dimensions and likely future. We argue that academic analysis is needed, to better understand the power dynamics operating within the gig economy and how these are testing existing norms and institutions. We discuss two mains ways that employment relations researchers can expand their theoretical repertoires and, in doing so, improve the evidence on gig-based working arrangements. We begin to sketch the outlines of a systematic research agenda, by elaborating indicative questions that need addressing to advance understanding of 'gig work relations'. We caution, however, that academic analysis of the gig economy should not be predicated on an expectation that it is the future of work. A number of economic, industrial and political factors threaten to slow or halt the gig economy's growth.

\section{Introduction}

As researchers focused on work and employment relations, we can hardly fail to have noticed the upsurge of recent interest in the 'gig economy'. By this, we mean the rapid spread of start-ups that connect and mediate between buyers and sellers in a range of markets, but particularly markets for in-person services. Among the best-known are Uber (a ride-sharing service), Deliveroo (a food-courier service), and Airtasker (an online broker for odd jobs). These and other similar firms are frequently described as 'disruptors' of established markets and firms. In some cases, their influence also extends to cultivating new market niches, by 
bringing additional providers on-stream (e.g., restaurants that did not previously offer homedelivery) and by increasing ease of use for customers.

Work in the gig economy is structured around multi-party interactions. Platform companies develop proprietary applications ('apps'), which users download and register to use. These companies attempt to both maintain, and distance themselves from, responsibility over the markets their apps create. On the one hand, they retain control over the allocation of work, working conditions, and some prices (Scheiber, 2017). They impose minimum acceptable standards on workers (e.g., how long a meal takes to deliver) and can enforce these through disciplinary actions ranging from mild (cautioning) to severe (disbarment from the app). On the other hand, these companies deny certain responsibilities. They disavow ownership of whatever is bought or sold via their apps. They renounce the responsibilities of 'employers', as customarily defined, and identify only as 'technological companies' who provide a useful medium of exchange (Keany, 2015).

Buyers (customers) are the next corner of the interaction. This is the traveller who needs a ride, or the homeowner whose wall needs painting. Through the app, buyers nominate their requirements and specify other criteria, such as timeframe and location. Depending on the app, they may also be able to indicate a price range. The sellers (providers) are restaurants with meals to serve, or car-owners willing to drive. Depending again on the particular app, sellers may or may not determine prices. Sellers benefit from access to a customer base; in exchange, they typically pay a percentage of each transaction's value to the host platform.

The 'buyers' and 'sellers' described above might never meet. In many cases (e.g., Deliveroo), there is an additional go-between in the form of couriers, who deliver meals to their buyers. These workers are the final main party to gig-economy transactions. They, too, are sellers in a classic sense: they offer labour power and time, and have no effective individual price-setting 
capacity. Their pay rates vary according to aggregate labour supply and demand within the markets created by each app - over which platform companies exert considerable influence and control. Those who work in the gig economy do have limited autonomy in two respects: they can choose whether to work (logging off when unavailable) and can offer their services to several apps at once. Platform companies emphasise both types of discretion, to insist that couriers/drivers are 'independent contractors' or 'freelancers', rather than employees (Bailey, 2016; Hatch, 2016). This classification of platform workers is perhaps the most controversial aspect of the gig economy. It allows platform companies to avoid (for now) some obligations of direct employment. Instead, some of these companies resort to extraordinary methods of surveillance and psychological manipulation to coordinate workers' activities and maintain service standards (Peetz, 2016; Scheiber, 2017).

The level of interest in the gig economy at times seems out of proportion to its actual impact on the economy. In the United States, Mishel (2015) estimated that payments to Uber drivers represent a tiny fraction (less than $0.01 \%$ ) of private-sector compensation. Similarly, the most detailed Australian study to date estimated that less than half of one per cent of adults were doing regular platform work (i.e., more than once per month) (Minifie and Wiltshire, 2016). These figures imply that, even if the gig economy is growing fast, it remains a minor feature of the broader labour market landscape for now.

And, yet, discussions of the 'future of work' - how much work will be available, how it will be arranged, and the impacts of technological change - frequently refer to the gig economy. One reason is that platform-based work models represent a continuation of longer-term trends (Stanford, 2017). In many developed economies, work has been radically overhauled since the 1980s in pursuit of greater 'flexibility' and cost savings. The result for many workers has been increased insecurity of employment and earnings, the loss of in-work benefits, and the splintering of internal and external career paths. No nation has moved further along this path 
than the United States. Among the many consequences of this shift is that today over 40 per cent of Americans work on a 'contingent' basis - in part-time, on-call, and contract roles without the security of permanent employment (Pofeldt, 2015; Weil, 2017). In Australia, similar trends are evident. Over a decade ago, researchers warned that growing reliance on non-standard employment threatened greater 'fragmentation' of incomes and opportunities (Watson et al., 2003). Today, 27 per cent of Australia's private-sector workforce is casually employed, and the figure is 35 per cent for workers without post-school qualifications (ABS, 2016). It is difficult not to see even more contingent forms of work in the platform economy as an extension of these historical developments.

Our question, then, is whether, as scholars of work and employment relations, we should take the gig economy seriously as a focus of inquiry, or whether it is too peripheral and ephemeral to justify close attention at this stage. Our answer turns on what we know so far about how the gig economy works, and how we expect it to develop in the near future. In what follows, we explore these issues and offer an assessment of the available evidence. We conclude with an outline of issues that invite closer scrutiny, and comment on how these might be pursued.

\section{Work in the gig economy: What we know so far}

The rise of the gig economy has brought new possibilities and problems for employment relations. Many academics, trade unionists and current or former gig workers have voiced concerns about the possible negative effects of platform companies' business and labour practices. Some allege that platforms facilitate 'sham contracting' by enabling businesses to disguise employment as independent contracting and avoid employee entitlements, such as superannuation (Bornstein, 2015). There is also apprehension about the return of 'spot labour markets', once common in agricultural and factory work at times of high unemployment, and now re-appearing in the digital economy. Today's anxious, disenfranchised workers wait for 
the next 'gig' to materialise on a smartphone, rather than waiting by the farm or factory gate (Sundararajan, 2016).

The ambiguous employment status of gig-economy workers is a major concern for critics of the platform model. While the challenge of correctly classifying different types of workers is itself not new, the involvement of new technology-driven business models, linked to more elaborate working arrangements, has aggravated existing definitional tensions. The presence of platforms as new intermediaries in the job market has spurred an important conversation about the suitability of current legal classifications, and the need for alternative categories.

Generally, platform companies have maintained that those working via their apps are independent contractors. Their argument is that contractors choose when and where to work, and must invest their own capital (e.g., a car or bike) to set up in operation. There is hostility to any suggestion that independent contractors should be legally reclassified as employees; some even venture to suggest that this would destroy the platform economy (Sherk, 2016). But even the staunchest advocates of the independent-contractor classification concede that gig-based work can resemble some elements of conventional employment: predetermined rates of pay, clothing and grooming requirements, and other performance criteria (Eisenbrey and Mishel, 2016; Sherk, 2016).

In an attempt to resolve this tension, some scholars have suggested that new legal categories are needed for gig workers. In the European literature, Todoli-Signes (2017) has argued for a 'special labour law' to cover the 'profession' of online platform work, which would cater to the eccentricities of new gig-based working arrangements. Special labour laws already apply in certain occupations, such as to lawyers and domestic workers, in Italy and Spain (TodoliSignes, 2017). In the United States, Harris and Krueger (2015) proposed a compromise legal category: 'independent workers'. In their view, 'work relationships arising in the "online gig 
economy" do not fit the existing legal definitions of "employee" or "independent contractor" status.' Settling the ambiguity with a new legal category would mean that the courts are not forced to choose between ill-suiting options, which could lead to confusing or contradictory precedents. In Harris and Krueger's (2015) proposal, independent workers would get some employee entitlements, such as the right to organise and bargain collectively, but not others, such as the minimum wage.

These authors use the case of Uber to illustrate the need for a new independent-worker category. The main issue they see, and the reason that they propose to exclude independent workers from hours-based employee entitlements, including the minimum wage, is that gig workers' hours are 'immeasurable' in practice. While they are logged into the Uber app and waiting for the next job to appear, workers are not idle: they can do personal tasks or can be engaged in other paid activities. Most importantly, workers can 'double-up'; while waiting for a job on Uber, drivers can be working for one of Uber's competitors. The difficult issue identified here by Harris and Krueger is that, while each app can readily measure how many hours a driver is logged-in, those hours cannot be uniquely assigned to a specific employer.

Other authors, however, question the difficulty of assigning workers' hours to one employer. Eisenbrey and Mishel (2016) note that Uber already has a guaranteed wage program, which relies on measuring the time drivers are logged-in. Conceptually, they argue that the platform whose job a driver ultimately accepts should pay for the time spent logged-in and waiting for that job. This approach puts a heavier onus on platform companies to manage the flow of jobs, to minimise workers' idle time between assignments. Eisenbrey and Mishel (2016) also see practical limits to workers 'doubling-up': in Uber, for instance, drivers must accept rides quickly while logged-in or they are penalised. Hence, while workers can log in to multiple apps at once, this is potentially risky and could harm the performance ratings that they rely on for continued access to the platforms. 
For these reasons, Eisenbrey and Mishel (2016) contend that drivers' working hours can and should - be assigned to specific platforms for compliance purposes. They see no reason (technical or conceptual) why gig workers are denied the hours-based entitlements available to employees in the United States, especially the minimum wage - which happens to be well above Uber's 'guaranteed wage'. Other observers have expressed concern that a new worker category, like the one devised by Harris and Krueger, may lead to deliberate misclassification as businesses attempt to bypass labour standards (Burns, 2017).

The issue of how gig work is treated legally - and the broader question of what rights and entitlements these workers should receive - remains 'live' as authorities around the world pass judgments on platform companies. Already, there are rulings favouring both sides: a decision last year in the United Kingdom deemed London's Uber drivers to be employees (Employment Tribunals, 2016), while a Florida appeals court later upheld Uber's position that its drivers are independent contractors (Hanks, 2017). Elsewhere in the United States, Uber has settled two separate class-action lawsuits brought by drivers, with large financial payouts, while retaining the right to engage its drivers as contractors (McCormick, 2016).

A further critique of the gig economy relates to its potential for accelerating 'fragmentation': breaking down once-whole jobs into discrete task elements, each of which is then auctioned to the lowest bidder. This fragmentation process has been taking place in Australia for some time; Watson et al. (2003) saw it as a threat not only to labour standards but to broader social protections and employment opportunities. With increasing disparities in job quality, those without access to the 'good' jobs would find it increasingly challenging to escape from low pay and employment insecurity (Kalleberg, 2012). The concern is that platform companies are now finding new technological means of accelerating this process of fragmentation and, in turn, fast-tracking its negative social effects. Indeed, gig work may be resurrecting a type of labour market that trade unions and regulators have long resisted - one in which workers 
must undercut each another for advantage, precipitating a 'race to the bottom' on wages and other performance expectations (e.g., delivery times).

In one high-profile expression of this view, Unions New South Wales (2016) argued that the online gig economy uses new technology as a 'fig leaf' to conceal old methods of worker exploitation. Its report characterises the platform business model as 'unregulated Taylorism', allied to a 'Dickensian marketplace' that is fragmenting working standards and disintegrating whole jobs into on-demand tasks, without the employment safety nets traditionally afforded to workers. The Economist (2015: p.63) labelled this process 'digital Taylorism': a modernday version of 'scientific management', in which technology is used 'to break complex jobs down into simple ones; measure everything that workers do; and link pay to performance, giving bonuses to high-achievers and sacking sluggards'.

Of course, there is also a more upbeat narrative about the benefits of gig-based work. Optimistic observers see a newly empowered, flexible workforce that can choose when and where to work, or if to work at all. Some go further, suggesting that the gig economy can help to match workers with job opportunities and thus reduce the incidence of underemployment (Macken, 2017). Others highlight the benefits of ready access to an 'on-demand' workforce for consumers and small business operators.

Minifie and Wiltshire (2016) contend that the growth of gig work could significantly expand opportunities for 1.1 million unemployed and under-employed Australians. Similarly, but on a global scale, Manyika et al. (2015) claim that tens of millions of jobseekers will find work through platforms in coming decades. These authors estimate that 30 to 45 percent of the world's working-age population is underutilised (inactive, unemployed, or working less than desired) and that many could be (re-) engaged through gig work. Finally, in the context of the slow recovery of the mainstream job market in Europe since the Great Recession, Fabo et al. 
(2017) suggested that gig-based work arrangements 'could benefit particularly discouraged and disadvantaged workers by offering them the possibility to work remotely' (p.3).

These expectations are not necessarily supported by the available empirical data, however. In a study of Uber drivers in the United States, Hall and Krueger (2015) found that more than 80 per cent were already employed before joining Uber. This suggests that, for most, gig work is a supplementary activity done irregularly to 'smooth' fluctuations in their primary earnings.

Depictions of platform work as a new wave of opportunity for the unemployed may thus be overstated. Ultimately, those wanting to participate in the gig economy need to meet certain standards (e.g., having a clean, late-model car) and master certain skills (e.g., interpersonal skills, to elicit favourable customer ratings). There is nothing to suggest that these skill and capital requirements are radically different from those required in the mainstream economy. Thus, while the gig economy may allow some workers to smooth their volatile incomes, it is unlikely (on its own) to help large numbers of jobseekers who face other significant barriers to entering employment.

For those who have already joined the gig economy, there are questions over whether and how such workers might shape the conditions of platform work to their advantage. Media reporting on gig workers' experiences suggests that they struggle to make ends meet, face risks to their health and safety, and resent intrusive surveillance of their work performance (Funnell, 2016). Anecdotal evidence similarly shows that there are limits to what gig workers are willing to endure, with some starting to resist and mobilise collective action against the platform companies. Last year, protests over working conditions by Deliveroo and Foodora drivers in London and Italy generated considerable publicity. These events demonstrate the potential for digital technologies to augment and complement direct action, with gig workers using social media outlets to build 'digital solidarity' with their demands (Stalder, 2013). 
In Australia, drivers working for apps such as Uber have recently established 'union-like' organisations to represent their interests, including Ride Share Drivers United (RSDU) and the Ride Share Drivers' Association of Australia. RSDU is one of several organisations using novel technological strategies to organise gig workers; the association has built its own app to facilitate communication between members and co-ordinate collective action. While it is too soon to judge the success of these mobilisation efforts, they suggest that gig workers have an appetite for 'voice' and are seeking new mechanisms for its expression (Greenhouse, 2016).

The ability of gig workers to secure decent work will depend, in part, on the response of 'traditional' unions. Internationally, some of these unions have actively supported gig workers in their struggles. In the United Kingdom, the union GMB instigated the landmark case to (successfully) challenge the status of Uber drivers as independent contractors. In Australia, Unions NSW recently published a report on Airtasker, arguing that the company undermines employment standards by engaging its workers as contractors. Following this report, Unions NSW and Airtasker reached an agreement, announced in May 2017, to have award pay rates shown on the platform, to offer workers discounted access to insurance (at their own expense), and to introduce voluntary dispute resolution procedures facilitated by the Fair Work Commission (Minter, 2017; Patty, 2017).

The grassroots campaigns of gig workers may also hold lessons for traditional unions about the uses of digital technology and ways of developing resonant frames that can mobilise a more fragmented and insecure workforce (Gahan and Pekarek, 2013). With ongoing declines in union density and collective bargaining coverage (Nicholson et al., 2017), it is both an imperative and a challenge for unions to make inroads into the gig economy. This endeavour would be aided by better knowledge of how gig workers construct their occupational interests and identities. Similarly, leading platform companies are multinational corporations, and might thus provide scope for transnational worker organising and representation efforts. 
The trajectory of gig work and workers' representation will also be shaped by how platform companies respond to demands for fairness and voice. In particular, the centrality of branding for platform companies makes them vulnerable to 'naming and shaming', implying that gig workers may be able to leverage consumer solidarity for their campaigns.

\section{Where is the gig economy going?}

The gig economy is still a relatively new phenomenon. Its leading firms have grown prodigiously in popularity and revenue in just a few years. Its proponents and detractors both seem to believe that further growth is inevitable. Yet there is little that is certain about how the gig economy will develop in the years ahead. Our reading of the literature suggests that there are five main paths that the gig economy might take, which we consider in this section. These five directions represent a mixture of opportunities, inherent limitations, and threats. Some may be serious enough to jeopardise the gig economy's long-term viability. Watching how these different possibilities 'play out' will, in our view, help to inform further academic study of the gig economy.

1. The business cycle. A major test for the gig economy is whether it can survive the next upswing in the business cycle. At present, many of the developed economies are enduring a prolonged recovery from the Global Financial Crisis. In Australia, business and labour market conditions remain weak, with low business confidence and investment, interest rates near zero, negligible wages growth, and widespread under-employment (ABS, 2017; Davidson, 2017; Healy, 2016). These are near-perfect conditions for the (re-)emergence of gig work. On the one hand, businesses are reluctant to hire new workers into ongoing jobs. At the same time, there is a long 'queue' of prospective workers looking to gain experience or earn some extra income. There is evidence that platform companies exploit this advantageous labour surplus, by offering new recruits attractive starting wages that 
are then whittled down over time as more and more workers join an app (Jacobs, 2017). The 'crunch' for many platforms will arrive when labour market conditions improve and workers have alternatives to the gig economy. Will this form of work then be sufficiently attractive for enough workers? Platform companies may be forced to modify elements of their practices to retain better workers, just as traditional employers must do when dealing with skill shortages (Richardson, 2009; Rosenblat, 2016). The extent of adjustment will also depend on Australia's migration policies, which have recently created what Boucher (2016) and others call a 'de facto low skilled migration program', with a steady supply of potential gig workers.

2. New and expanded regulation. The spectre of governments intervening in gig markets, through new forms of regulation, is an enduring concern for platform companies. This threat is taken seriously enough that some major gig firms, such as Uber, have appointed former senior political advisors as their lobbyists (Ruthhart and Dardick, 2017). Some jurisdictions have outlawed certain gig businesses (e.g. ride-share apps) (Rhodes, 2017), but Australian regulators have generally been more permissive (the Northern Territory is a notable exception here). Nonetheless, labour market and other regulators in a range of areas stand poised to upset the common platform business model. One line of challenge is through the legal system, with continuing efforts to have gig workers deemed as platform employees. In a 2016 decision on Uber's treatment of its drivers as contractors, a United Kingdom tribunal declared: 'The notion that Uber in London is a mosaic of 30,000 small businesses linked by a common "platform" is to our mind faintly ridiculous' (Employment Tribunals, 2016: p.28; Johnston, 2016). Similar cases have been prosecuted in other jurisdictions. As yet, there is no clear precedent; decisions contrary to platforms' interests are open to appeal, and may be overturned. But definitive future rulings could substantially harm the arms-length, low-cost labour strategies on which many platforms 
rely, by requiring them to honour regular employment obligations, such as (in Australia) paid leave and superannuation. This explains why major platforms are so determined to avoid terminology that could be taken to imply the existence of conventional, dependent employment relationships (Butler, 2017). The potential reach of new regulation does not end with formal legal proceedings over employment classification issues, however. The Australian Taxation Office is investigating gig companies, including Uber, in relation to both company tax obligations and income taxes owed by their contractors (McCauley, 2016). There are murmurings of similar interest from authorities in the United Kingdom (Booth, 2017). As the gig economy expands in size and visibility, the platform operators' self-image (and implicit self-defence) as mere 'technology companies' - and not transport companies, hoteliers, etc. - appears to be wearing thin (Keany, 2015). Further regulatory problems lurk for platform companies in relation to safety, with Uber, in particular, being cast as a riskier mode of transport because its vehicles are not required to be fitted with the same passenger safety technologies as licenced taxis (Toscano, 2015). These sorts of concerns bubble away below the surface of ease and flexibility cultivated by the platform companies. How these issues are resolved will determine the longer-term viability of the platform model and the kind of 'social licence' with which gig firms continue to operate.

3. 'Bridges and traps'. While it would be useful to have a more reliable 'snapshot' of the workers who are part of the gig economy right now, there is an even more pressing need for evidence of what happens to these workers over time. One proposition is that gig work imparts skills that help inexperienced workers move into subsequent higher-paid or more secure jobs. Empirical investigations of this kind have been done previously in Australia with respect to casual employment (Watson, 2013), but comparable evidence does not yet exist for freelancers in the gig economy, due to both the newness of this sector and data limitations. Evidence of this potential 'stepping-stone' effect will be even more valuable 
if it can be shown that the gig economy brings marginal jobseekers into employment, as some have suggested (Minifie and Wiltshire, 2016). It is also possible to imagine gig work becoming the default point of labour market entry for graduates. Weakness in the graduate labour market has coincided with a rapid growth in unpaid internships being offered in place of ongoing paid employment (Healy, 2016; Stewart and Owens, 2013). The gig economy might have a role in helping new workers to navigate this challenging initial phase of their working life, if operates as a 'bridge'. The extent to which it can do this in practice matters enormously, in light of technological developments in artificial intelligence that are eliminating graduate-level professional jobs (Susskind and Susskind, 2015; Walsh, 2017). At this point, however, the notion of gig work as a step on the ladder to better employment is mere conjecture. The unappealing alternative view (also yet to be tested) is of gig work as a 'trap'. Instead of providing jobseekers with a pathway into the mainstream workforce, perhaps the gig economy isolates them and provides a negative signal to other employers of a potential worker's productivity. Only longitudinal data can sort out which of these competing propositions is more accurate. In Australia, the easiest way to collect such data on gig workers would be to augment the Household, Income and Labour Dynamics in Australia (HILDA) survey with a module of new, tailored questions.

4. Moving upstream. Insofar as can be discerned from the limited evidence available, the varieties of work on offer in the gig economy today seem largely confined to the lower end of the labour market. This observation is consistent with the informal nature of gig work, the absence of ongoing employment contracts, the appeal to jobseekers and the underemployed, and the sub-minimum wages some gig workers earn. Macken (2017: 9) memorably captured the low-end nature of many gig-economy opportunities, describing them as 'stuff-my-partner-won't-do'. The calibre of work accessible at this stage in the gig economy's development means that certain in-built limits to its further expansion 
have sometimes been assumed. The Grattan Institute, for instance, noted that platforms have limited penetration in markets 'where work is required on a continuous basis, involves complex teamwork, or requires deep knowledge of [a] workplace' (Minifie and Wiltshire, 2016: 36). The implication is that platforms might continue to expand their presence within certain unskilled labour markets, but would have difficulty gaining a foothold in areas where conventional working arrangements are better established or in some sense required. Such assumptions about the feasible boundaries of the gig economy may, however, need revising, in light of some recent examples of platform companies that have found ways to 'move upstream' into markets and occupations that were previously off-limits. Macken (2017) provides examples of new platforms emerging for services in accounting, consulting, and legal work, which were until recently seen as inviolable. Even sensitive and highly personalised areas of work, such as the caring professions, have new platforms appearing at their edges. Better Caring is one such company attempting to enter the market for disability care services. If platforms can branch out into even these more demanding markets, the gig economy may outgrow its original limitations and become a permanent alternative to both established firms and 'traditional' modes of employment.

5. Workers as owners. A final possible direction for the gig economy is a move away from current ownership models toward more worker-led, 'co-operative' models. At present, most platforms are owned by their developers. As noted earlier, these entrepreneurs have strenuously resisted responsibility as employers, and too often gig workers' experiences have been neglected in pursuit of other commercial goals (Pazaitis et al., 2017; Scheiber, 2017). Platform companies have faced, and will continue to face, multiple challenges to their business model while the interests of their owner-developers diverge so markedly from the interests of their contract/freelance workers. Yet, there is no reason why current ownership models should always prevail. Experience to date suggests that, once an app is 
created and in use, its functions can be easily 'cloned' by rival firms. Uber and Lyft offer similar platforms in the ride-sharing space, as do Deliveroo and Foodora in the foodcourier market. But if other companies can copy the dominant platforms' apps, they need not also copy their ownership models. There are already some examples of what Scholz (2016) calls 'platform cooperatives': organisations that mimic the apps of the leading platforms and marry these to worker-friendly ownership structures. In the United States, unionised taxi drivers have developed ride-sharing apps owned by members; revenues are returned to drivers through healthcare, pensions and other benefits. These worker-owned platforms face many challenges in competing with established companies, but there is no technological reason why more cannot emerge. Such ownership models may prove to be more sustainable in the gig economy than the present reliance on freelancers, given the insistent problems arising from this approach around legal compliance and exploitation.

\section{How should we study the gig economy? Towards a research agenda}

Our view is that the gig economy deserves serious attention from the community of work and employment relations scholars, to scrutinise, critique and add much-needed depth to the evidence available. There are many questions unanswered and much that is not yet known, including who exactly works in the gig economy, why they do so, how much they earn from it, and whether such participation offers a pathway into more traditional employment (indeed, if that transition is even desired). On the platform companies' side, there are questions about optimal human resource and wage-setting practices, such as how to handle high turnover of workers and perceptions of unfair treatment. For legal scholars, many issues stem from the gig economy's challenge to established modes of regulation in employment, safety, taxation and other areas of the law. And, finally, there is work for employment relations scholars in theorising the gig economy, especially in terms of the power relations between 'employers', workers and consumers. 
What approaches should be used by those attempting to analyse this new corner of working life? There is ongoing debate over the need for employment relations scholarship to broaden its theoretical scope, in order to maintain relevance in a rapidly changing world of work (Edwards, 2005; Kaufman, 2008; Jackson et al., 2013). As well as providing employment relations scholars with a new research focus, the gig economy suggests promising directions for theoretical dialogue and exchange with cognate literatures and fields.

We highlight two possible sites of interdisciplinary engagement, for illustrative purposes, while recognising that there may be many other ways to expand the theoretical horizons of employment relations (Jackson et al., 2013). We then suggest some questions for empirical research that begin to develop the basis of a gig-economy research agenda.

Institutional analysis has always featured strongly in employment relations scholarship, reflecting a long-standing concern with the origins, evolution and effects of rules governing the employment relationship (Kaufman, 2008). Yet, certain strands of institutional theorising have been less widely utilised, including organisational (or sociological) institutionalism (Morgan and Hauptmeier, 2014). With its recent focus on how actors and processes help to create, maintain and disrupt institutions (Lawrence et al., 2009), organisational institutionalism offers conceptual tools that are highly relevant for making sense of work in the gig economy. An emerging literature demonstrates the potential value of blending organisational institutionalism and employment relations, with recent studies focusing on transnational labour negotiation (Helfen and Sydow, 2013), the adoption of new organisational templates in unions (Yu, 2013), and the legitimation of temporary agency work (Helfen, 2015). We have argued that the labour practices used by platform companies represent a challenge to current institutional settlements. Research drawing on elements of both organisational institutionalism and employment relations provides a promising avenue for analysing the consequences of this challenge. 
Second, with its focus on the 'roots of activism' and the dynamics of mobilisation, contestation and repression (Tapia et al., 2015; forthcoming), social movement theory offers scope for analytical refinement and theoretical revitalisation in employment relations (Gahan and Pekarek, 2013). This potential is most evident in Kelly's (1998) use of concepts from social movement theory to develop 'mobilization theory' as a framework for understanding the processes by which workers join together and take collective action. Since then, researchers informed by both employment relations and social movement theory have made important advances, including in relation to the role of framing processes in union strategy (Heery and Conley, 2007), the evolving nature of labour solidarity (Heckscher and McCarthy, 2014), and the different forms of member mobilisation across organisational cultures (Tapia, 2013). We have discussed manifestations of protest by gig workers and pointed to examples of new, union-like organisations forming in response to untenable working conditions. A perspective grounded in employment relations and social movement theory offers a strong analytical foundation for making sense of these mobilisations and their longer-term contributions to developing workers' voice and representation. A blended theoretical perspective also offers an attractive basis for comprehending corporate (and political) efforts that are directed at counter-mobilisation, repression and accommodation.

In order to further sketch the outline of a research agenda for employment relations scholars concerned with the gig economy, we now suggest some specific questions that could inform empirical and theoretical research.

Worker voice and representation in the gig economy are fundamental concerns. More specific questions that might be examined in this vein include:

- How do gig workers negotiate their work and non-work identities? How do these identities matter in struggles for respect, representation and fair conditions in and around platform companies? 
- What scope is there for gig workers to represent themselves vis-à-vis employers and the state, both individually and collectively?

- How can unions reorganise to represent gig workers?

Our paper has highlighted that the business models and human-resource practices of platform companies are not well understood. Indicative research questions that would help to address these gaps in the evidence include:

- What scope is there for gig firms to take a 'high-road' approach to human resource management?

- How do gig firms respond when challenged by workers and their representative organisations?

Research is also needed to analyse the contours of gig-based labour markets, and how these interact with labour markets more broadly. Future research could consider:

- To what extent are existing social inequalities intensified or ameliorated through gig work?

- Why are gig workers prepared to labour under inferior employment terms and conditions?

Questions of regulation have been central to public controversies around the gig economy. In order to develop new understandings, and deepen these conversations, researchers might ask:

- Which forms of labour market regulation are most effective in the gig economy?

- How can regulatory approaches to gig work found overseas be translated into the Australian context?

While it is beyond the scope of this paper to provide a comprehensive research agenda, our discussion suggests some theoretical and empirical directions that are likely to be fruitful in gaining a better understanding of 'gig work relations'. As noted, there are a number of key 
facets of the gig economy that remain inadequately understood; thus, a more comprehensive research agenda will need to be developed iteratively. As more scholarly evidence comes to light, new and different questions will arise.

\section{Conclusion}

Academic study of the gig economy is just beginning. The quantity of popular commentary and speculation vastly exceeds the quality and depth of the evidentiary base and a significant effort will be required to develop a strong understanding of how many people work in the gig economy, why they do it, and how trade unions, regulators and scholars should respond to it. However, none of this should hinge on an expectation that gig-based work is necessarily the future of work. We identified several limits to the gig economy's growth, and some of these may prove to be existential threats.

The most useful contribution that employment relations scholars can make is to move beyond the many polarised assessments that characterise the gig economy as exclusively good or bad. Under what conditions - and for whom - might gig work be beneficial? What instruments can regulators use to 'nudge' platform companies towards better labour-management practices? Variants of these questions have always been of interest to employment relations researchers. The gig economy challenges us to re-examine what 'decent work' means in the $21^{\text {st }}$ century and recommit to achieving it universally.

\section{$\underline{\text { References }}$}

ABS (Australian Bureau of Statistics) (2017) 'Media release: Wages growth remains at record low', Wage Price Index, Australia, Dec 2016. ABS catalogue no. 6345.0, Canberra.

ABS (Australian Bureau of Statistics) (2016) Characteristics of Employment, Australia, August 2015, Data cubes, '6 EMPLOYED PERSONS: Selected characteristics-By status of employment in main job', ABS catalogue no. 6333.0, Canberra. 
Bailey, M. (2016) 'Deliveroo boom faces Fair Work reality check', Australian Financial Review, 9 August 2016. Available at: http://www.afr.com/technology/deliverooboom-faces-fair-work-reality-check-20160809-gqok7n (accessed 29 March 2017).

Bornstein, J. (2015) 'The great Uber fairness fallacy: As a driver, how do you bargain with an app?' The Guardian, 25 August 2015. Available at: http://bit.ly/2wrvd57 (accessed 1 September 2017).

Booth, R. (2017) 'Tax barrister plans to take Uber to court over alleged $£ 20 \mathrm{~m}$ black hole', The Guardian, 22 February 2017. Available at: http://bit.ly/2mbhxpe (accessed 1 September 2017).

Boucher, A. (2016) 'Australia's de facto low skilled migration program', pages 43-54 in CEDA (Committee for the Economic Development of Australia) (2016) Migration: The Economic Debate, Melbourne.

Burns, R. (2017) ‘Bargaining with Silicon Valley’, Dissent, Winter 2017.

Butler, S. (2017) 'Deliveroo accused of "creating vocabulary" to avoid calling couriers employees', The Guardian, 6 April 2017. Available at: https://www.theguardian.com/business/2017/apr/05/deliveroo-couriers-employeesmanagers (accessed 6 April 2017).

Davidson, H. (2017) 'Third of Australian youth have no job or are underemployed, report finds', The Guardian, 27 March 2017. Available at: https://www.theguardian.com/business/2017/mar/27/third-of-australian-youth-haveno-job-or-are-underemployed-report-finds (accessed 29 March 2017)

Edwards, P. (2005). 'The challenging but promising future of industrial relations: Developing theory and method in context-sensitive research', Industrial Relations Journal, 36(4): 264-282.

Eisenbrey, R. and Mishel, L. (2016) 'Uber business model does not justify a new “independent worker" category', Economic Policy Institute. Available at: http://www.epi.org/publication/uber-business-model-does-not-justify-a-newindependent-worker-category/ (accessed 13 April 2017).

Employment Tribunals (2016) 'Aslam and Farrar v Uber: Reasons for the reserved judgment on preliminary hearing sent to the parties on 28 October 2016', Case Nos: 2202550/2015 \& Others, Available at: https://www.judiciary.gov.uk/wpcontent/uploads/2016/10/aslam-and-farrar-v-uber-reasons-20161028.pdf (accessed 29 March 2017).

Fabo, B., Karanovic, J. and Dukova, K. (2017) 'In search of an adequate European policy response to the platform economy', Transfer: European Review of Labour and Research, Online First (accessed 1 May 2017). 
Funnell, A. (2016) 'The contingent workforce and the growth of digital Taylorism', ABC Radio National, Future Tense, 28 August 2016. Available at: http://ab.co/2p7CdPf (accessed 4 May 2017).

Gahan, P. and Pekarek, A. (2013) 'Social movement theory, collective action frames and union theory: A critique and extension', British Journal of Industrial Relations, 51(4): 754-776.

Greenhouse, S. (2016) 'On demand, and demanding their rights', The American Prospect, Summer 2016. Available at: http://prospect.org/article/demand-and-demanding-theirrights (accessed 10 May 2017).

Hanks, D. (2017) 'Uber wins big in court after Miami driver denied unemployment benefits', Miami Herald, 1 February 2017. Available at: http://www.miamiherald.com/news/local/community/miamidade/article130050824.html (accessed 12 April 2017).

Hall, J. and Krueger, A. (2015) 'An analysis of the labor market for Uber's driver-partners in the United States', Princeton University, Industrial Relations Section, Working Paper No. 587.

Harris, S. and Krueger, A. (2015) 'A proposal for modernizing labor laws for twenty-firstcentury work: The "independent worker"', Brookings Institution, The Hamilton Project, Discussion paper 2015-10.

Hatch, P. (2016) 'Deliveroo and foodora accused of using sham contracts for bicycle delivery riders', The Sydney Morning Herald, 30 March 2016. Available at: http://www.smh.com.au/business/workplace-relations/deliveroo-and-foodoraaccused-of-using-sham-contacts-for-bicycle-delivery-riders-20160329-gnsu7g.html (accessed 29 March 2017).

Healy, J. (2016) 'The Australian labour market in 2015', Journal of Industrial Relations, 58(3): 308-323.

Heery, E. and Conley, H. (2007) 'Frame extension in a mature social movement: British trade unions and part-time work, 1967-2002', Journal of Industrial Relations, 49(1): 5-29.

Heckscher, C. and McCarthy, J. (2014) 'Transient solidarities: Commitment and collective action in post-industrial societies', British Journal of Industrial Relations, 52(4): 627657.

Helfen, M. (2015) 'Institutionalizing precariousness? The politics of boundary work in legalizing agency work in Germany, 1949-2004', Organization Studies, 36(10): 13871422.

Helfen, M. and Sydow, J. (2013) 'Negotiating as institutional work: The case of labour standards and international framework agreements', Organization Studies, 34(8): 1073-1098. 
Jackson, G., Kuruvilla, S., and Frege, C. (2013) 'Across boundaries: The global challenges facing workers and employment research', British Journal of Industrial Relations, 51(3): 425-439.

Jacobs, E. (2017) 'The gig economy: Freedom from a boss, or just a con?' New Statesman, 20 March 2017. Available at: http://www.newstatesman.com/politics/economy/2017/03/gig-economy-freedomboss-or-just-con (accessed 29 March 2017)

Johnston, C. (2016) 'Uber drivers win key employment case', BBC News, 28 October 2016. Available at: http://www.bbc.com/news/business-37802386 (accessed 29 March 2017).

Kalleberg, A. (2012). 'Job quality and precarious work: Clarifications, controversies, and challenges', Work and Occupations, 39(4): 427-448.

Kaufman, B. (2008) 'Paradigms in industrial relations: Original, modern and versions inbetween', British Journal of Industrial Relations, 46(2): 314-339.

Keany, F. (2015) 'Uber calls for investigation into Australian Tax Office as it defends tax affairs in Australia', ABC News, 18 November 2015. Available at: http://ab.co/2mOxDZR (accessed 29 March 2017).

Kelly, J. (1998) Rethinking Industrial Relations: Mobilisation, Collectivism and Long Waves, Routledge Studies in Employment Relations series, Routledge, London.

Lawrence, T., Suddaby, R. and Leca, B. (2009) Institutional Work: Actors and Agency in Institutional Studies of Organizations, Cambridge University Press, Cambridge, UK.

Macken, D. (2017) ‘The gig economy’, The Deal, 91 (March 2017): 8-11.

McCauley, D. (2016) 'Tax Office cracks down on sharing economy', News.com.au, 24 June 2016. Available at: http://www.news.com.au/finance/small-business/tax-officecracks-down-on-sharing-economy/news-story/55bfade6f14168c42bc7f9f444e 781f7 (accessed 29 March 2017).

McCormick, R. (2016) 'Uber settles lawsuits to keep drivers as independent contractors in California and Massachusetts', The Verge, 21 April 2016. Available at: http://www.theverge.com/2016/4/21/11485424/uber-suit-california-Massachusettsdrivers-employee-contractor (accessed 12 April 2017).

Minifie, J. and Wiltshire, T. (2016) Peer-to-peer pressure: Policy for the sharing economy, Grattan Institute Report no. 2016-7, Melbourne.

Minter, K. (2017) 'Negotiating labour standards in the gig economy: Airtasker and Unions New South Wales', The Economic and Labour Relations Review, 28(3): 438-454.

Mishel, L. (2015) 'Uber is not the future of work', The Atlantic, 16 November 2015. Available at: http://theatln.tc/2m6QICq (accessed 28 March 2017) 
Morgan, G. and Hauptmeier, M. (2014) 'Varieties of institutional theory in comparative employment relations', in A. Wilkinson, G. Wood and R. Deeg (eds.) Handbook of Employment Relations: Comparative Employment Systems, Oxford University Press, Oxford, pp. 190-221.

Nicholson, D., Pekarek, A. and Gahan, P. (2017) 'Unions and collective bargaining in Australia in 2016', Journal of Industrial Relations, 59(3).

Patty, A. (2017) 'Airtasker and unions make landmark agreement to improve pay rates and conditions', The Sydney Morning Herald, 1 May 2017. Available at: http://www.smh.com.au/business/workplace-relations/airtasker-and-unions-makelandmark-agreement-to-improve-pay-rates-and-conditions-20170427-gvtvpo.html (accessed 2 May 2017).

Pazaitis, A., Kostakis, V. and Bauwens, M. (2017) 'Digital economy and the rise of open cooperativism: the case of the Enspiral Network', Transfer: European Review of Labour and Research, Online First (accessed 1 May 2017).

Peetz, D. (2016) 'Why the death of employment is a dead idea', The Conversation, 13 May 2016. Available at: https://theconversation.com/why-the-death-of-employment-is-adead-idea-58736 (accessed 4 April 2017).

Pofeldt, E. (2015) 'Shocker: 40\% of workers now have "contingent” jobs, says US government', Forbes, 25 May 2015. Available at:

https://www.forbes.com/sites/elainepofeldt/2015/05/25/shocker-40-of-workers-nowhave-contingent-jobs-says-u-s-government/ (accessed 28 March 2017)

Rhodes, A. (2017) 'Uber: Which countries have banned the controversial taxi app', Independent, 3 May 2017. Available at: http://ind.pn/2p4QtrX (accessed 25 August 2017).

Richardson, S. (2009) 'What is a skill shortage?' Australian Bulletin of Labour, 35(1): 326354.

Rosenblat, A. (2016) 'What motivates gig economy workers?' Harvard Business Review, 17 November 2016. Available at: https://hbr.org/2016/11/what-motivates-gig-economyworkers (accessed 11 April 2017).

Ruthhart, B. and Dardick, H. (2017) 'Former Obama aide fined $\$ 90,000$ for illegally lobbying Emanuel on Uber's behalf', Chicago Tribune, 16 February 2017. Available at: http://trib.in/21QvH2n (accessed 1 September 2017).

Scheiber, N. (2017) 'How Uber uses psychological tricks to push its drivers' buttons', New York Times, 2 April 2017. Available at: https://nyti.ms/2nMmDtc (accessed 4 April 2017).

Sherk, J. (2016) 'The rise of the "gig" economy: Good for workers and consumers', The Heritage Foundation. Available at: http://www.heritage.org/jobs-and-labor/report/therise-the-gig-economy-good-workers-and-consumers (accessed 13 April 2017). 
Stalder, F. (2013) Digital Solidarity, Mute, in association with Post-Media Lab Books, Leuphana University.

Stanford, J. (2017) 'The resurgence of gig work: Historical and theoretical perspectives', The Economic and Labour Relations Review, 28(3): 382-401.

Stewart, A. and Owens, R. (2013) Experience or Exploitation? The Nature, Prevalence and Regulation of Unpaid Work Experience, Internships and Trial Periods in Australia, Report for the Fair Work Ombudsman, Melbourne.

Sundararajan, A. (2016) The Sharing Economy: The End of Employment and the Rise of Crowd-Based Capitalism, Cambridge: Massachusetts Institute of Technology Press.

Susskind, R. and Susskind, D. (2015) The Future of the Professions: How Technology Will Transform the Work of Human Experts, New York: Oxford University Press.

Tapia, M. (2013) 'Marching to different tunes: Commitment and culture as mobilizing mechanisms of trade unions and community organizations', British Journal of Industrial Relations, 51(4): 666-688.

Tapia, M., Elfström, M. and Roca-Servat, D. (Forthcoming). 'Bridging social movement and industrial relations theory: An analysis of worker organizing campaigns in the US and China', Research in the Sociology of Organizations (RSO), Volume on 'Social Movements, Stakeholders, and Non-Market Strategy'.

Tapia, M., Ibsen, C. and Kochan, T. (2015) 'Mapping the frontier of theory in industrial relations: The contested role of worker representation', Socio-Economic Review, 13(1): 157-184.

The Economist (2015) 'Digital Taylorism: A modern version of "scientific management" threatens to dehumanise the workplace', The Economist, 12 September 2015, 416(8955): 63.

Todoli-Signes, A. (2017) 'The "gig economy": Employee, self-employed or the need for a special employment regulation?' Transfer: European Review of Labour and Research, Online First (accessed 1 May 2017).

Toscano, N. (2015) 'UberX: companies "face penalties" for use of ride-share service', The Age, 21 April 2015. Available at: http://www.theage.com.au/digital-life/smartphoneapps/uberx-companies-face-penalties-for-use-of-rideshare-service-20150412-1mjb6r (accessed 29 March 2017).

Unions New South Wales (2016) 'Innovation or exploitation: Busting the Airtasker myth', Unions NSW, Sydney. Available at: http://apo.org.au/node/68082 (accessed 13 April 2017).

Walsh, T. (2017) It's Alive! Artificial Intelligence from the Logic Piano to Killer Robots, Melbourne: La Trobe University Press. 
Watson, I. (2013) 'Bridges or traps? Casualisation and labour market transitions in Australia', Journal of Industrial Relations, 55(1): 6-37.

Watson, I., Buchanan, J., Campbell, I. and Briggs, C. (2003) Fragmented Futures: New Challenges in Working Life, Sydney: The Federation Press.

Weil, D. (2017) 'How to make employment fair in an age of contracting and temp work', Harvard Business Review, 24 March 2017. Available at:

https://hbr.org/2017/03/making-employment-a-fair-deal-in-the-age-of-contractingsubcontracting-and-temp-work (accessed 28 March 2017).

Yu, K. (2013) 'Institutionalization in the context of institutional pluralism: Politics as a generative process', Organization Studies, 34(1): 105-131. 